\section{Kidney \\ Blood Pressure Research}

Kidney Blood Press Res 2015;40:153-165

DOI: 10.1159/000368491

Published online: March 29, 2015

Accepted: February 23, 2015

\title{
Impact of Phosphorus Restriction and Vitamin D-Substitution on Secondary Hyperparathyroidism in a Proteinuric Mouse Model
}

\author{
Bernhard N. Bohnert ${ }^{a} \quad$ Christoph Daniel ${ }^{b} \quad$ Kerstin Amann $^{b} \quad$ Jakob Voelkl ${ }^{c}$ \\ Ioana Alesutanc ${ }^{c}$ Florian Lang ${ }^{c}$ Nils Heyne ${ }^{a}$ Hans-Ulrich Häring ${ }^{a}$ \\ Ferruh Artunc ${ }^{a}$
}

aDepartment of Internal Medicine, Division of Endocrinology, Diabetology, Vascular Disease, Nephrology and Clinical Chemistry, University Hospital Tübingen, Tübingen; ${ }^{b}$ Department of Nephropathology, University Hospital Erlangen, Erlangen; 'Department of Physiology, University of Tübingen, Tübingen, Germany

\section{Key Words}

SHPT • Nephrotic syndrome $•$ Mice $・$ Phosphorus

\begin{abstract}
Background/Aims: Since the discovery of FGF23, secondary hyperparathyroidism (SHPT) in renal disease has been considered to result primarily from phosphorus retention rather than vitamin D deficiency. However, the impact of phosphorus restriction and vitamin D supplementation on SHPT is still ill defined. Methods: We investigated the development of SHPT in a doxorubicin-induced proteinuric mouse model and tested different treatment strategies including a low phosphorus diet and substitution with native or active vitamin D in 129 S1/SvImJ wild-type mice. Results: Development of SHPT at day 30 was strongly related to the magnitude of induced proteinuria. In mice with a proteinuria $<100 \mathrm{mg} / \mathrm{mg}$ creatinine, SHPT was mild (PTH increase 2.4-fold), and serum levels of FGF23, phosphate and urea remained almost stable, whereas mice with heavy proteinuria ( $>100 \mathrm{mg} / \mathrm{mg}$ creatinine) developed marked SHPT (PTH increase 10.1-fold) accompanied by massive increase in FGF23 (27.0-fold increase), hyperphosphatemia (1.8-fold increase), renal failure (7.3-fold urea increase) and depletion of both $25-\mathrm{OH}$ vitamin $\mathrm{D}$ and $1,25-\mathrm{OH}$ vitamin $\mathrm{D}$. Substitution with native or active vitamin D was unable to suppress SHPT, whereas a low-phosphorus diet ( $P_{i}$ content $0.013 \%$ ) completely suppressed SHPT in mice with both mild and heavy proteinuria. Conclusions: The development of SHPT resulted from phosphate retention in this proteinuric model and could completely be suppressed with a low-phosphorus diet.
\end{abstract}




\section{Kidney Blood Pressure Research}

Kidney Blood Press Res 2015;40:153-165

\begin{tabular}{l|l}
\hline DOI: 10.1159/000368491 & (C) 2015 S. Karger AG, Basel
\end{tabular}

Published online: March 29, 2015

www.karger.com/kbr

Bohnert/Daniel/Amann/Voelkl/Alesutan/Lang/Heyne/Häring/Artunc: Secondary Hyperparathyroidism And Proteinuric Mouse Model

\section{Introduction}

The traditional concept for explaining secondary hyperparathyroidism (SHPT) relied on a disturbed calcium balance and vitamin D deficiency, however, after the discovery and identification of fibroblast growth factor 23 (FGF23) as an essential phosphatonin [1-2], retention of phosphorus has been regarded as a central motif in the early stages of SHPT [3]. The current notion is that increased parathyroid hormone (PTH) and FGF23 secretion act in concert to prevent hyperphosphatemia by increasing renal phosphate excretion [4-5]. Studies in animals [6] and humans [3] show that the increase in FGF23 is the first abnormality detected in early SHPT, followed by an increase in PTH and decrease in vitamin D (both active and native) [7]. FGF23's actions also include downregulation of $1 \alpha$-hydroxylase in the proximal tubule, thereby reducing levels of active vitamin $\mathrm{D}$ [2]. Abolishing the effects of FGF23 with an antibody was found to exacerbate hyperphosphatemia while normalizing $1,25-\mathrm{OH}$ vitamin D levels in rats with chronic renal failure [6]. The effects of FGF23 are dependent on the transmembrane protein klotho, which converts the canonical FGF receptor into a specific FGF23 receptor [8]. Loss of renal parenchyma leads to reduced klotho expression and FGF23 resistance partially explaining the increase in FGF23 secretion during renal failure.

Despite the progress in the pathophysiological understanding of SHPT, the optimal treatment strategy to prevent and halt SHPT in patients with predialysis chronic kidney disease (CKD) is not known. The options include substitution of native or active vitamin D, dietary phosphorus restriction, phosphate binders or calcimimetics. KDIGO guidelines recommend substitution of vitamin $\mathrm{D}$ in cases of low 25-OH vitamin D serum levels and treatment with active 1,25-OH vitamin D in states of progressive SHPT $[9,10]$. Arguing from a phosphocentric prespective, vitamin $\mathrm{D}$ treatment should increase phosphate absorption from the gut and exacerbate phosphate load. However, active vitamin $\mathrm{D}$ is a potent suppressor of PTH gene expression [11] and its production is often decreased in CKD. Theoretically, vitamin D deficiency in CKD patients could also result from urinary losses of vitamin D binding protein (VDBP), which carries 25-OH vitamin $\mathrm{D}$ to the proximal tubule where uptake occurs by megalin and is followed by PTH-stimulated hydroxylation at $\mathrm{C} 1$. Therefore, quantitatively relevant losses of VDBP could occur during gross proteinuria [12]. In a small study by Doorenbos et al. [13], urinary VDBP excretion was increased by nearly 100-fold in non-nephrotic CKD patients and correlated closely to proteinuria $(\mathrm{r}=0.85)$. However, no relationship was observed between VDBP losses and plasma 25-OH vitamin D and 1,25$\mathrm{OH}$ vitamin D concentrations. This might be completely different in patients with nephrotic syndrome where relevant vitamin D losses have been reported [13, 14]. Altogether, there is a paucity of data regarding vitamin $\mathrm{D}$ balance in patients with nephrotic syndrome, particularly in adults.

In this study, we investigated the development of SHPT during the progression of renal failure in a proteinuric mouse model that recapitulates all stages of chronic kidney disease [15] and is associated with vitamin D deficiency due to urinary loss [16]. We then tested whether substitution of native or active vitamin D or dietary phosphorus restriction was able to prevent SHPT in this model.

\section{Materials and Methods}

Animals

Experiments were performed on wild-type 129 S1/SvImJ mice purchased from Charles River, Germany. Mice were kept on a 12:12-h light-dark cycle and fed a standard diet (C1000, phosphorus content 7.5 g/kg, Altromin, Lage, Germany) with tap water ad libitum. All animal experiments were conducted according to the German law for the welfare of animals and were approved by local authorities.

To induce the proteinuric mouse model, 8-month-old mice were treated with a single intravenous injection of doxorubicin ( $2 \mu \mathrm{g} / \mu \mathrm{l}$, Cell Pharm, Bad Vilbel, Germany) into the left retrobulbar venous plexus 


\section{Kidney Blood Pressure Research}

under light isoflurane anesthesia. The dose of doxorubicin was 12.6 $\mu \mathrm{g} / \mathrm{g}$ bw for the induction of CKD 1-3, $14 \mu \mathrm{g} / \mathrm{g}$ bw to induce CKD 4-5 and $15.4 \mu \mathrm{g} / \mathrm{g}$ bw to induce AKI. Samples of spontaneously voided urine were collected in the morning 2 days before (baseline) and up to 30 days following doxorubicin injection. Blood samples were drawn before and on day 10 and 30 after doxorubicin injection.

Treatments to suppress SHPT consisted of a low-phosphorus diet (C1048, phosphorus content $0.13 \mathrm{~g} / \mathrm{kg}$, Altromin, Lage, Kidney Blood Press Res 2015;40:153-165

\begin{tabular}{l|l}
\hline DOI: $10.1159 / 000368491$ & C 2015 S. Karger AG, Basel \\
Published
\end{tabular}

Bohnert/Daniel/Amann/Voelkl/Alesutan/Lang/Heyne/Häring/Artunc: Secondary Hyperparathyroidism And Proteinuric Mouse Model

Table 1. Number of injected animals of the respective series with non-nephrotic (CKD 1-3) mice and mice died before reaching the endpoint

\begin{tabular}{lccc}
\hline & injected & $\begin{array}{c}\text { non- } \\
\text { nephrotic }\end{array}$ & $\begin{array}{c}\text { lost } \\
\text { animals }\end{array}$ \\
\hline control series & 18 & 12 & 2 \\
$\quad$ - end point day 10 & 19 & 7 & 5 \\
$\quad$ - end point day 30 & 16 & 6 & 5 \\
preemptive treatment series & 14 & 4 & 3 \\
$\quad$ - low Pi diet & 18 & 8 & 2 \\
- 25-OH vit. D treatment & & & \\
- 1,25-OH vit. D treatment & 14 & 0 & 3 \\
interventional treatment series & & 0 & 1 \\
$\quad$ - control group & & & \\
$\quad$ - therapy group & & & \\
\hline
\end{tabular}

Germany) or a diet enriched with cholecalciferol (C1000 + 25000 IE/kg, Altromin, Lage, Germany). In CKD 4-5 mice, cholecalciferol (D3-Vicotrat, $100000 \mathrm{IE} / \mathrm{ml}$, Heyl, Berlin, Germany) had to be injected at a dose of $15 \mathrm{IE} / \mathrm{g}$ bw three times per week i.p. to overcome proteinuric losses and to achieve normalization of 25-0H vitamin D concentration. 1,25-OH-treatment consisted of three i.p. injections per week at a dose of $100 \mathrm{pg} / \mathrm{g}$ bw in CKD 1-3 and 300 $\mathrm{pg} / \mathrm{g}$ bw in CKD 4-5 mice. Table 1 depicts the number of injected animals of the respective series.

\section{Laboratory assays}

Urea, phosphorus, calcium and protein were measured with colorimetric assays (Labor+Technik, Berlin, Germany). Free calcium was measured using IL GEM® Premier 3000 blood gas analyzer (Instrumentation laboratory GmbH, Kirchheim, Germany). PTH, FGF23, 25-OH vitamin D and 1,25-OH vitamin D concentrations were measured using ELISA kits (Immutopics, CA, USA and IDS Immunodiagnostic Systems, Frankfurt am Main, Germany).

\section{Quantitative RT-PCR measurements}

Transcript levels of klotho, $1 \alpha$ - and 24-hydroxylase in kidneys from untreated or treated mice were measured using LightCycler System (Roche Diagnostics, Mannheim, Germany) as described previously [17]. Primers and conditions are shown in Table 2. Amplified products were confirmed by melting curve analysis and sequencing. Results were expressed as a ratio of the target versus the housekeeping gene GAPDH transcripts.

\section{Histopathological analysis}

Mouse kidneys were fixed in 4\% paraformaldehyde/0.1 M sodium phosphate buffer pH 7.4, dehydrated and embedded in paraffin. Kidneys were cut into 2- $\mu$ m-thick slices and stained with periodic acid Schiff's reagent. Sections were evaluated in a blinded fashion for signs of glomerular und tubular damage using semi-quantitative analysis by glomerular sclerosis index (GSI) [18] and tubular injury score (TSI) [19], respectively. Von-Kossa stainings from the kidneys as well as from a definite part of the thoracic aorta (transversal sections) were performed to investigate calcifications.

\section{Statistical analysis}

Data are provided as arithmetic means \pm SE, with $n$ representing the number of independent experiments. All of the data were tested for significance with parametric or nonparametric ANOVA, paired or unpaired Student's t-test, or Mann-Whitney U-test where applicable using GraphPad InStat and Prism 6, GraphPad Software (San Diego, CA, www.graphpad.com). A p value $<0.05$ was considered statistically significant. 


\section{Kidney \\ Blood Pressure Research}

\section{Kidney Blood Press Res 2015;40:153-165}

DOI: 10.1159/000368491

Published online: March 29, 2015

(C) 2015 S. Karger AG, Basel

www.karger.com/kbr

Bohnert/Daniel/Amann/Voelkl/Alesutan/Lang/Heyne/Häring/Artunc: Secondary

Hyperparathyroidism And Proteinuric Mouse Model

Table 2. Used primers and amplification protocols

\begin{tabular}{|c|c|c|c|c|c|}
\hline gene & \multicolumn{2}{|c|}{$\begin{array}{c}\text { sense/forward } \\
5^{\prime} \rightarrow 3 \text { ' orientation }\end{array}$} & \multicolumn{2}{|c|}{$\begin{array}{l}\text { antisense/reverse } \\
5^{\prime} \rightarrow 3^{\prime} \text { orientation }\end{array}$} & amplicon \\
\hline $\begin{array}{l}\text { 1 } \alpha \text {-Hydroxylase; } \\
\text { CYP27B1 } \\
\text { (Gene ID: } 13115 \text { ) }\end{array}$ & \multicolumn{2}{|c|}{ GCATCACTTAACCCACTTCC } & CGGGAAAG & TCATAGAGTGT & $135 \mathrm{bp}$ \\
\hline $\begin{array}{l}\text { 24-Hydroxylase; } \\
\text { CYP24A1 } \\
\text { (Gene ID: 13081) }\end{array}$ & \multicolumn{2}{|c|}{ CCCTTCTGCAAGAAAACTGC } & CTCTTGAG & CTCTGATTGG & $232 \mathrm{bp}$ \\
\hline $\begin{array}{l}\text { klotho } \\
\text { (Gene ID: 16591) }\end{array}$ & \multicolumn{2}{|c|}{ CCCTGTGACTTTGCTTGGG } & CCCACAGAT & AGACATTCGGGT & $91 \mathrm{bp}$ \\
\hline $\begin{array}{l}\text { GAPDH } \\
\text { (Gene ID: 14433) }\end{array}$ & \multicolumn{2}{|c|}{ AACGACCCCTTCATTGAC } & TCCACGAC & ACTCAGCAC & $191 \mathrm{bp}$ \\
\hline gene & $\begin{array}{c}\text { initial } \\
\text { denaturation }\end{array}$ & ycles & denaturation & $g$ & extension \\
\hline CYP & in; $95^{\circ} \mathrm{C}$ & 4. & $95^{\circ} \mathrm{C}$ & ${ }^{\circ} \mathrm{C}$ & $20 \mathrm{~s} ; 72^{\circ} \mathrm{C}$ \\
\hline klot & & 40 & & $5^{\circ} \mathrm{C}$ & $20 \mathrm{~s} ; 72^{\circ} \mathrm{C}$ \\
\hline GAPDH & $10 \mathrm{~min} ; 95^{\circ} \mathrm{C}$ & 35 & $15 \mathrm{~s} ; 95^{\circ} \mathrm{C}$ & $10 \mathrm{~s} ; 69^{\circ} \mathrm{C}$ & $9 \mathrm{~s} ; 72^{\circ} \mathrm{C}$ \\
\hline
\end{tabular}

\section{Results}

Induction of nephropathy

Eight-month-old wild-type 129 S1/SvImJ mice were injected with a single dose of doxorubicin to induce a kidney disease model corresponding to focal segmental glomerulosclerosis [15]. Depending on the dose of doxorubicin, three different courses of renal disease could be induced: acute kidney injury (AKI; 9.2-fold urea increase 10 days after injection), proteinuric chronic kidney disease with preserved GFR (CKD 1-3; no or minimal urea increase after 30 days) and progressive CKD (CKD 4-5; 7.3-fold urea increase after 30 days; Fig 1A). Proteinuria was highest in AKI mice, intermediate in mice with CKD 4-5 and lowest in mice with CKD 1-3 (Fig. 1B) and was associated with hypoproteinemia of different degrees according to magnitude of proteinuria (Fig 1C). Ten days after induction, a massive hyperphosphatemia was observed in AKI and to a lesser extent in CKD 4-5 mice that persisted throughout the course of the study (Fig. 1D). In contrast, phosphate levels remained stable in CKD 1-3 mice. In the urine, increased phosphaturia was observed in AKI and CKD 4-5 mice that decreased after day 20 (Fig. 1E). In all three groups, ionized calcium concentrations were nearly constant, with a slight tendency towards hypocalcemia in AKI and CKD 4-5 mice after 30 days (Fig. 1F). In the latter two groups, urinary calcium excretion increased transiently and subsequently returned to baseline values (data not shown).

\section{Development of SHPT}

CKD 4-5 mice developed massive SHPT (PTH increase 10.1-fold; Fig. 2A), whereas CKD 1-3 mice exhibited only a mild elevation of PTH (2.4-fold increase). In contrast, AKI mice did not develop SHPT. FGF23 concentrations were massively increased in AKI mice and to a lesser extent in CKD 4-5 mice, whereas plasma FGF23 did not persistently increase in CKD 1-3 mice (Fig. 2B). The pattern of the FGF23 response paralleled phosphate levels, and the correlation between phosphate and FGF23 concentrations was very high across all groups $(\mathrm{r}=0.77)$. Another striking finding was the depletion of both $25-\mathrm{OH}$ vitamin $\mathrm{D}$ and $1,25-$ $\mathrm{OH}$ vitamin D from the plasma in both AKI and CKD 4-5 mice within 10 days after onset of proteinuria (Fig. 2C,D). In these mice, 25-OH vitamin D was detectable in the urine (data not shown). In CKD 1-3 mice, 25-OH vitamin D concentrations decreased to a lesser extent and $1,25-\mathrm{OH}$ vitamin D concentrations were almost preserved. 


\section{Kidney \\ Blood Pressure \\ Research}

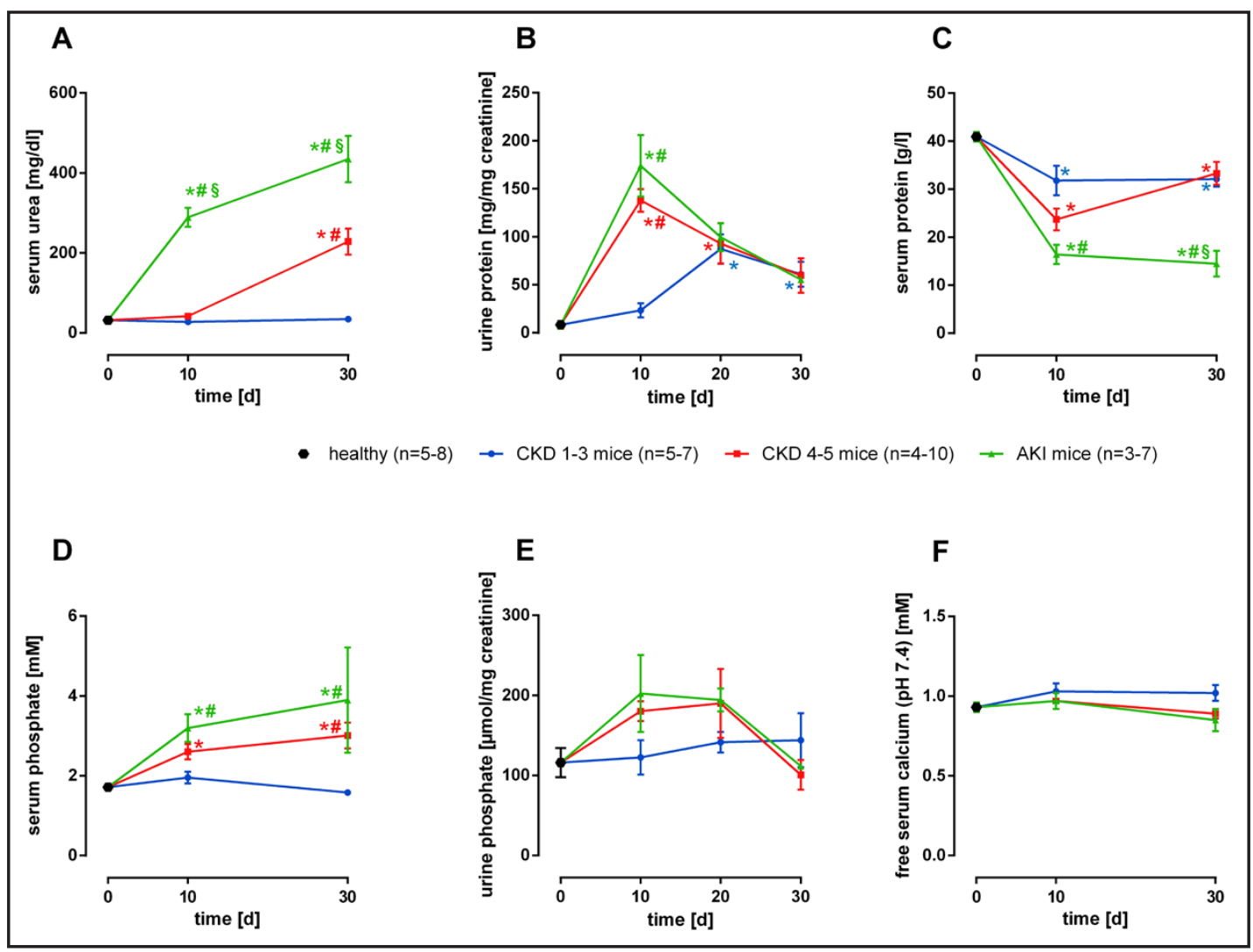

Fig. 1. Time course of serum urea (A), proteinuria (B), serum protein concentration $(C)$, serum phosphate concentration (D), phosphaturia (E) and concentration of ionized calcium (F) according to the severity of nephropathy. Arithmetic means \pm SEM. * indicates significant difference compared to control values in healthy mice, \# indicates significant difference compared to CKD 1-3 mice, § indicates significant difference compared to CKD 4-5 mice.

Expression of klotho, $1 \alpha$ - (encoded by Cyp27b1 gene) and 24-hydroxylase (encoded by Cyp24a1 gene) were analyzed at the mRNA level using quantitative RT-PCR (Fig. 3). In AKI and CKD 4-5 mice, there was a marked decrease in klotho expression $(0.20$ and 0.27 -fold, respectively) that was less pronounced in CKD 1-3 mice (0.56-fold). Interestingly, expression of $1 \alpha$-hydroxylase was increased in all groups by day 30, first being observed in AKI mice on day 10. Expression of 24-hydroxylase was induced in AKI and CKD 4-5 mice on day 10 and subsequently returned to control levels. In contrast, 24-hydroxylase levels in CKD 1-3 mice significantly decreased below control levels on day 30 .

\section{Therapeutic intervention}

After studying the development of SHPT in this model, we investigated whether substitution of native or active vitamin $\mathrm{D}$ to compensate for the massive vitamin $\mathrm{D}$ deficiency or dietary phosphorus restriction to correct massive hyperphosphatemia were able to prevent SHPT observed in CKD 1-3 or CKD 4-5 mice. As shown in Fig. 4A, SHPT could be completely prevented in both CKD 1-3 and CKD 4-5 mice with a low-phosphorus diet whereas the substitution of $25-\mathrm{OH}$ vitamin $\mathrm{D}$ or $1,25-\mathrm{OH}$ vitamin $\mathrm{D}$ was completely unable to suppress PTH secretion. Under a low phosphorus diet, FGF23 concentrations were lower than in untreated CKD 4-5 mice (Fig. 4B). Substitution of 25-OH vitamin D was sufficient to normalize plasma levels in CKD 1-3 and CKD 4-5 mice, whereas no other treatments affected 


\section{Kidney Blood Pressure Research}

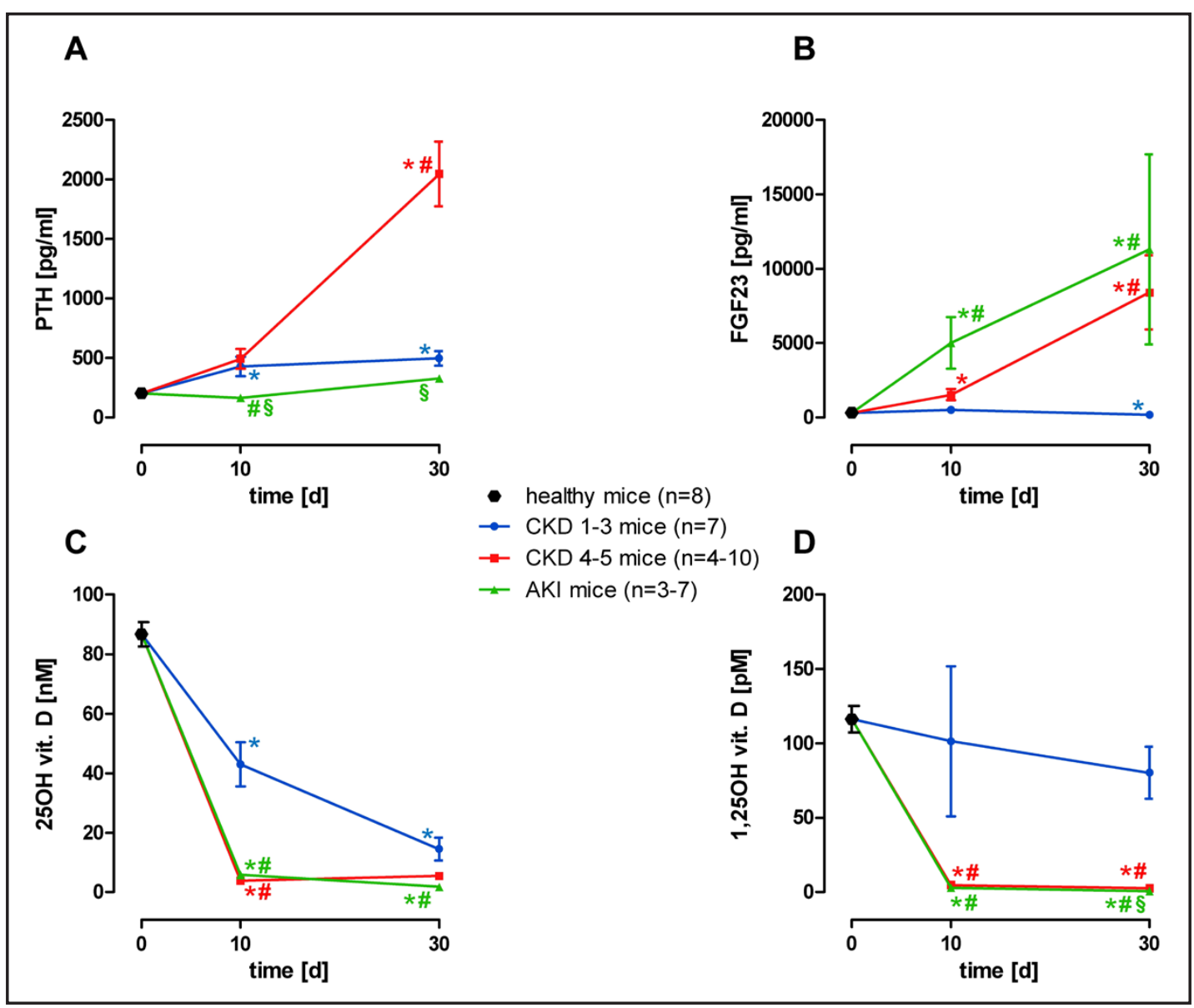

Fig. 2. Development of SHPT (A) and course of FGF23 (B) and serum concentrations of vitamin D metabolites (C, D). Arithmetic means \pm SEM. * indicates significant difference compared to control values in healthy mice, \# indicates significant difference compared to CKD 1-3 mice, § indicates significant difference compared to CKD 4-5 mice.

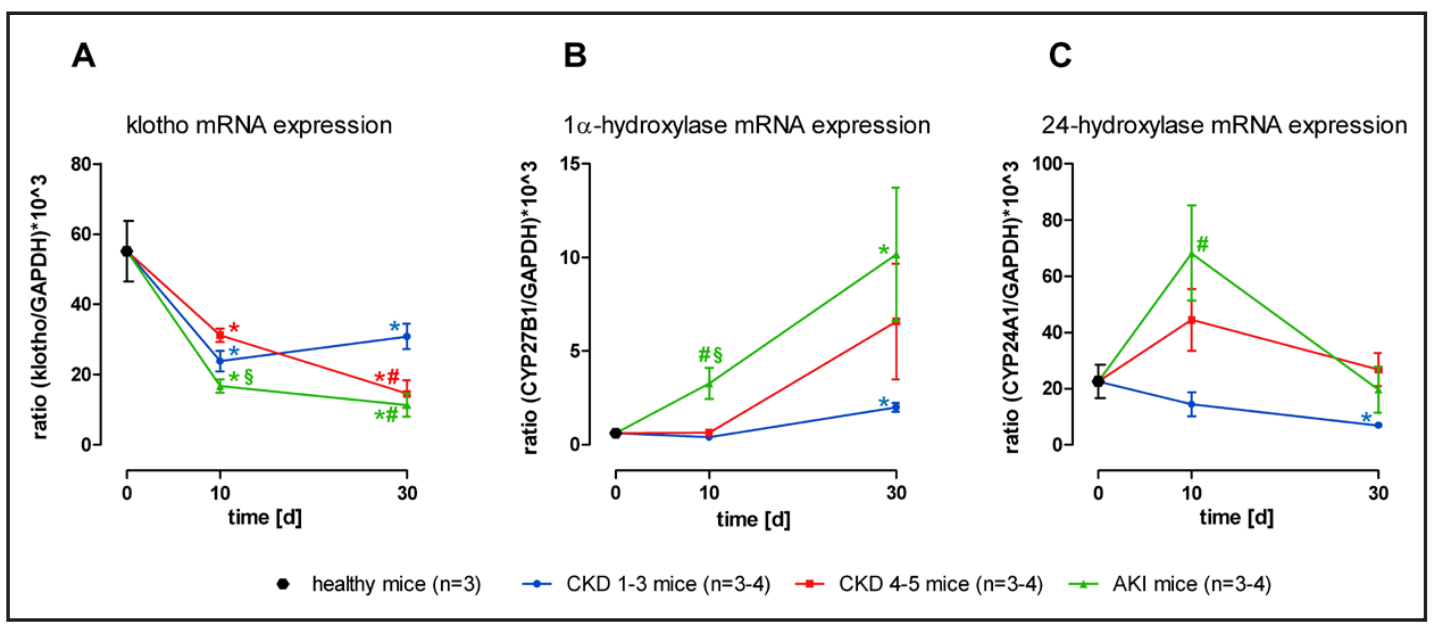

Fig. 3. Expression of klotho (A), 1 $\alpha$ - (B) and 24-hydroxylase (C) mRNA in the kidney. Arithmetic means \pm SEM. * indicates significant difference compared to control values in healthy mice, \# indicates significant difference compared to CKD 1-3 mice, § indicates significant difference compared to CKD 4-5 mice. 


\section{Kidney \\ Blood Pressure Research}

Kidney Blood Press Res 2015;40:153-165

\begin{tabular}{l|l}
\hline DOI: $10.1159 / 000368491$ & (c) 2015 S. Karger AG, Basel \\
\hline
\end{tabular}

Published online: March 29, 2015

www.karger.com/kbr

159

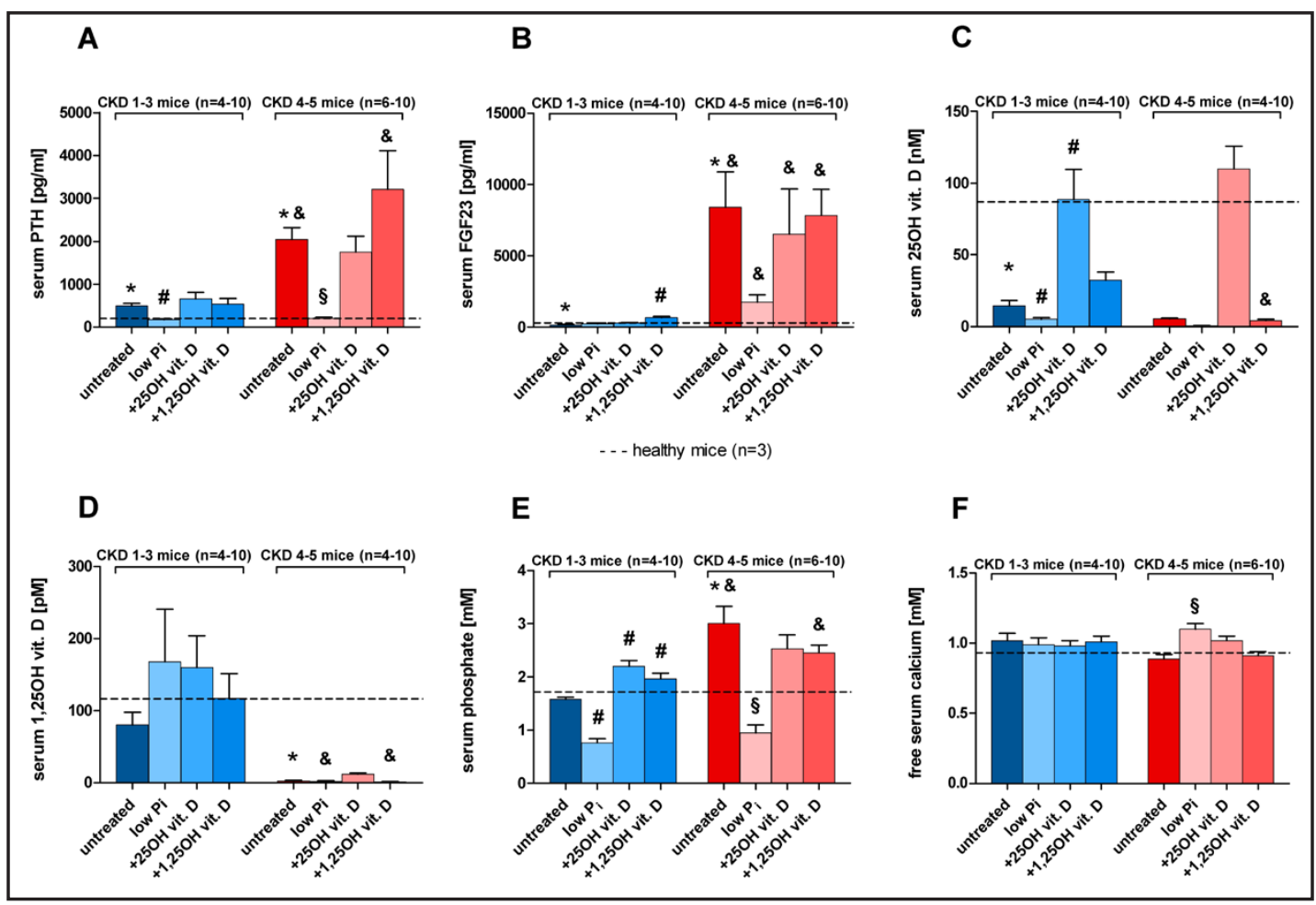

Fig. 4. Effects of various treatments on SHPT (A) and related parameters (B-F). Arithmetic means \pm SEM. * indicates significant difference between healthy und untreated mice with doxorubicin-induced nephropathy, \# indicates significant difference between untreated and treated CKD 1-3 mice, $\S$ indicates significant difference between untreated and treated CKD 4-5 mice, \& indicates significant difference between corresponding CKD 1-3 and CKD 4-5 mice.

25-OH vitamin D plasma concentrations (Fig. 4C). Plasma concentrations of 1,25-OH vitamin D remained normal during each treatment in CKD 1-3 mice, whereas no treatment could correct the depletion of the plasma concentrations of 1,25-OH vitamin D in CKD 4-5 mice (Fig. 4D). A low-phosphorus diet prevented hyperphosphatemia in mice with both CKD 1-3 and CKD 4-5, whereas treatment with $25-\mathrm{OH}$ vitamin $\mathrm{D}$ or $1,25-\mathrm{OH}$ vitamin $\mathrm{D}$ induced hyperphosphatemia in mice with CKD 1-3 (Fig. 4E). Concentrations of ionized calcium remained stable and were slightly increased in CKD 4-5 mice fed a low-phosphorus diet (Fig. $4 \mathrm{~F})$.

Treatment strategies had different effects on the mRNA expression of klotho, $1 \alpha$ - and 24-hydroxylase (Fig. 5). Klotho expression was not significantly affected by any treatment (Fig. 5A). Treatment with $25-\mathrm{OH}$ vitamin D or 1,25-OH vitamin D induced a marked increase in 24-hydroxylase expression in all groups (Fig. 5B). $1 \alpha$-hydroxylase levels were preserved in mice with CKD 1-3 fed a low-phosphorus diet and decreased under treatment with 25$\mathrm{OH}$ vitamin D or 1,25-OH vitamin D (Fig. 5C). In CKD 4-5 mice, $1 \alpha$-hydroxylase levels were decreased under treatment with a low-phosphorus diet and 25-0H vitamin D while there was an increase under treatment with 1,25-OH vitamin D.

Histological analysis of renal tissue revealed a marked increase in glomerular sclerosis index (GSI) in CKD 4-5 mice compared to CKD 1-3 mice that was significantly lower in mice treated with 25-OH vitamin D (Fig. 6). Tubular sclerosis index (TSI) was also increased in CKD 4-5 mice compared to CKD 1-3 mice, and there was a strong trend towards a reduction by a low-phosphorus diet and $25-0 \mathrm{H}$ vitamin $\mathrm{D}$ treatment, although not reaching statistical significance. None of the analyzed kidneys or aortae under any treatment displayed calcifications as analyzed with von-Kossa stainings. 


\section{Kidney \\ Blood Pressure Research}

\section{Kidney Blood Press Res 2015;40:153-165}

\begin{tabular}{l|l}
\hline DOI: $10.1159 / 000368491$ & (c) 2015 S. Karger AG, Basel \\
\hline
\end{tabular}

www.karger.com/kbr

Bohnert/Daniel/Amann/Voelkl/Alesutan/Lang/Heyne/Häring/Artunc: Secondary Hyperparathyroidism And Proteinuric Mouse Model

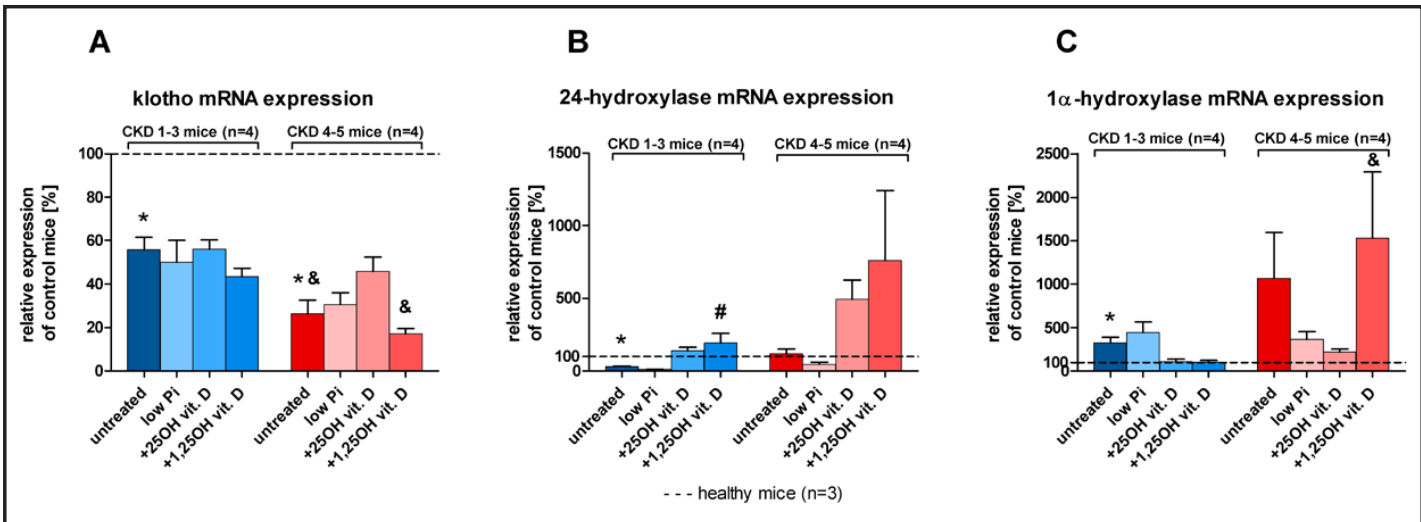

Fig. 5. Expression of klotho (A), 24- (B) and 1 $\alpha$-hydroxylase (C) mRNA during various treatments. Arithmetic means of values normalized to those in healthy control mice \pm SEM. * indicates significant difference between healthy und untreated mice with doxorubicin-induced nephropathy, \# indicates significant difference between untreated and treated CKD 1-3 mice, \& indicates significant difference between corresponding CKD 1-3 and CKD 4-5 mice.

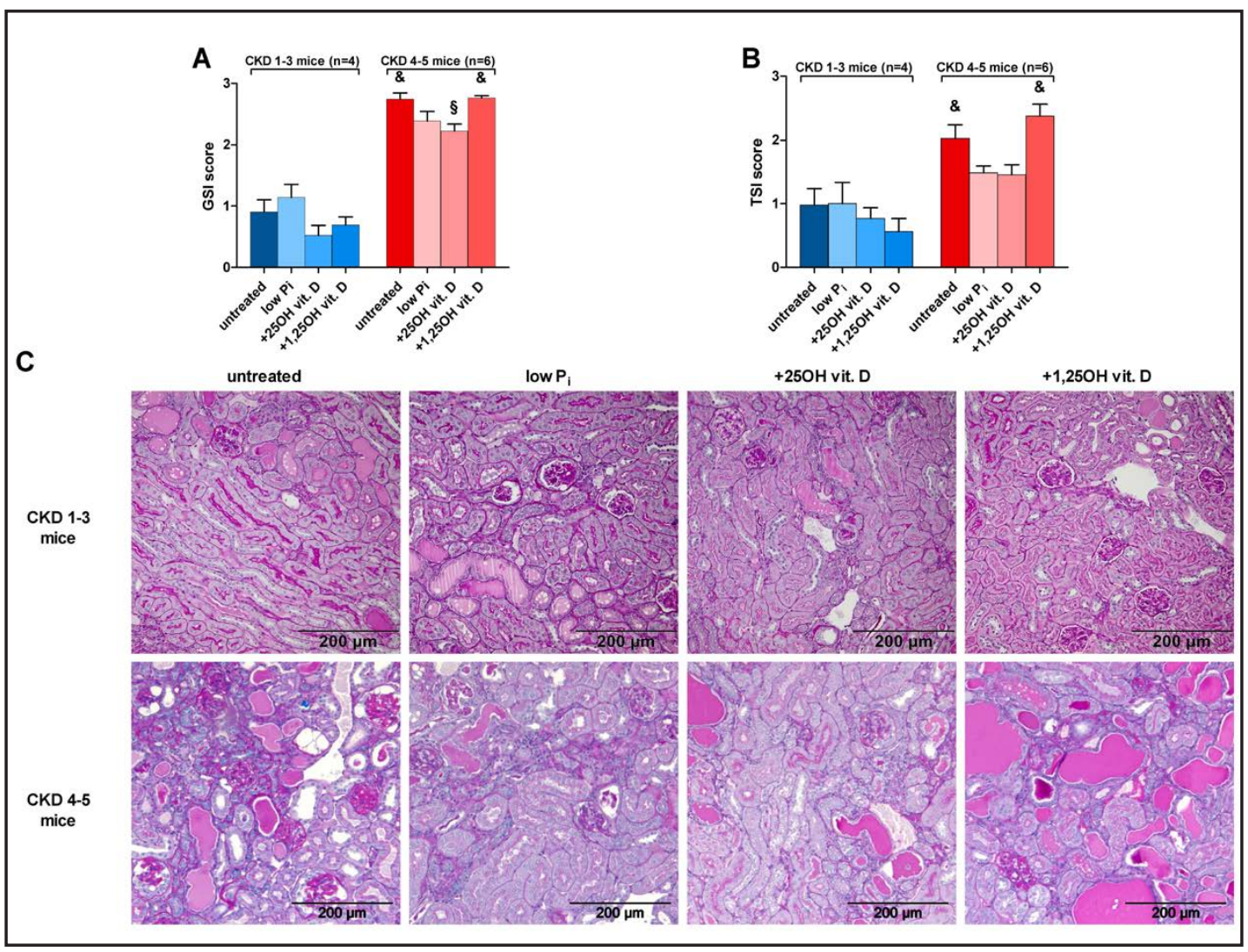

Fig. 6. Glomerular (A) and tubular (B) sclerosis index of mice with doxorubicin-induced nephropathy and different treatments. Representative light microscopic pictures (PAS, $100 \mathrm{x}$ magnification) showing typical histomorphological changes (C). Arithmetic means \pm SEM. $\S$ indicates significant difference between untreated and treated CKD 4-5 mice, \& indicates significant difference between corresponding CKD 1-3 and CKD 4-5 mice. 


\section{Kidney \\ Blood Pressure \\ Research}

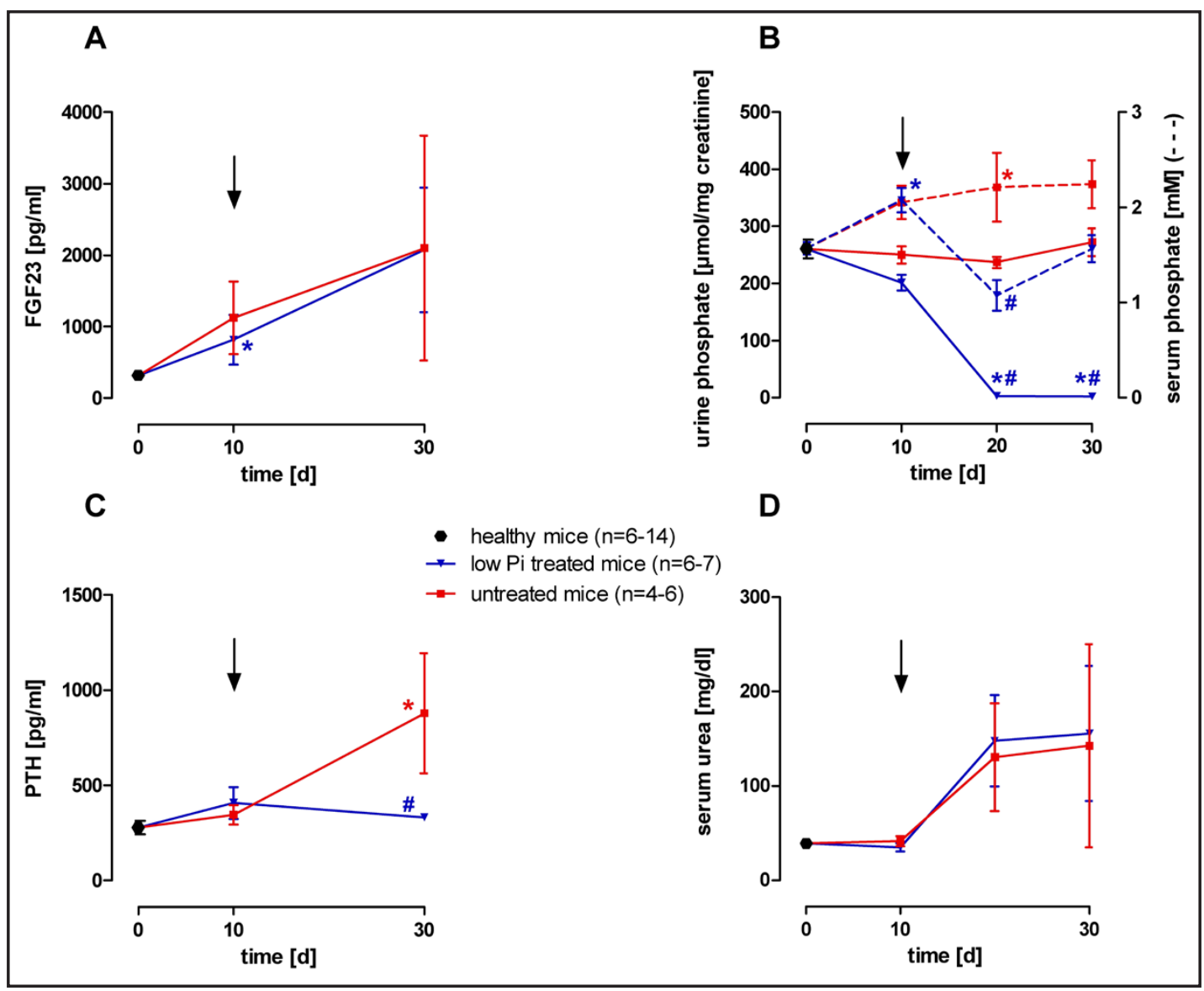

Fig. 7. Prevention of SHPT after the elevation of FGF23 concentrations by a low-phosphorus diet in CKD 4-5 mice. Arithmetic means \pm SEM. * indicates significant difference compared to control values in healthy mice, \# indicates significant difference compared to untreated CKD 4-5 mice, $\downarrow$ indicates the point of stratification and the start of treatment.

\section{Amelioration of progressive renal failure}

In his recent paper [20], Kuro-o proposed a paradigm shift in the treatment of CKDmineral bone disorder, in that increased FGF23 concentrations rather than phosphate should prompt treatment in predialysis CKD, with the aim of preventing renal injury by phosphaturia. To test this hypothesis, we treated CKD 4-5 mice with dietary phosphorus restriction as this had shown to reduce phosphaturia and suppress SHPT. Mice with increased FGF23 concentrations on day 10 after induction were stratified to control or low-phosphorus diet (Fig. 7A). At that time, all of the mice had mild hyperphosphatemia and phosphaturia (Fig. 7B), however, no SHPT (Fig. 7C). In mice that were treated with a low-phosphorus diet, hyperphosphatemia and phosphaturia were strikingly reduced, preventing the development of SHPT observed in mice fed a control diet. FGF23 concentrations remained stable in both arms. However, serum urea concentration, used as a marker of progressive renal failure, was not different between mice fed a low-phosphorus diet and mice fed a control diet (Fig. 7D).

\section{Discussion}

This study shows that the development of SHPT in this proteinuric model relied on phosphate retention and could be completely suppressed with a low-phosphorus diet, 


\section{Kidney Blood Pressure Research}

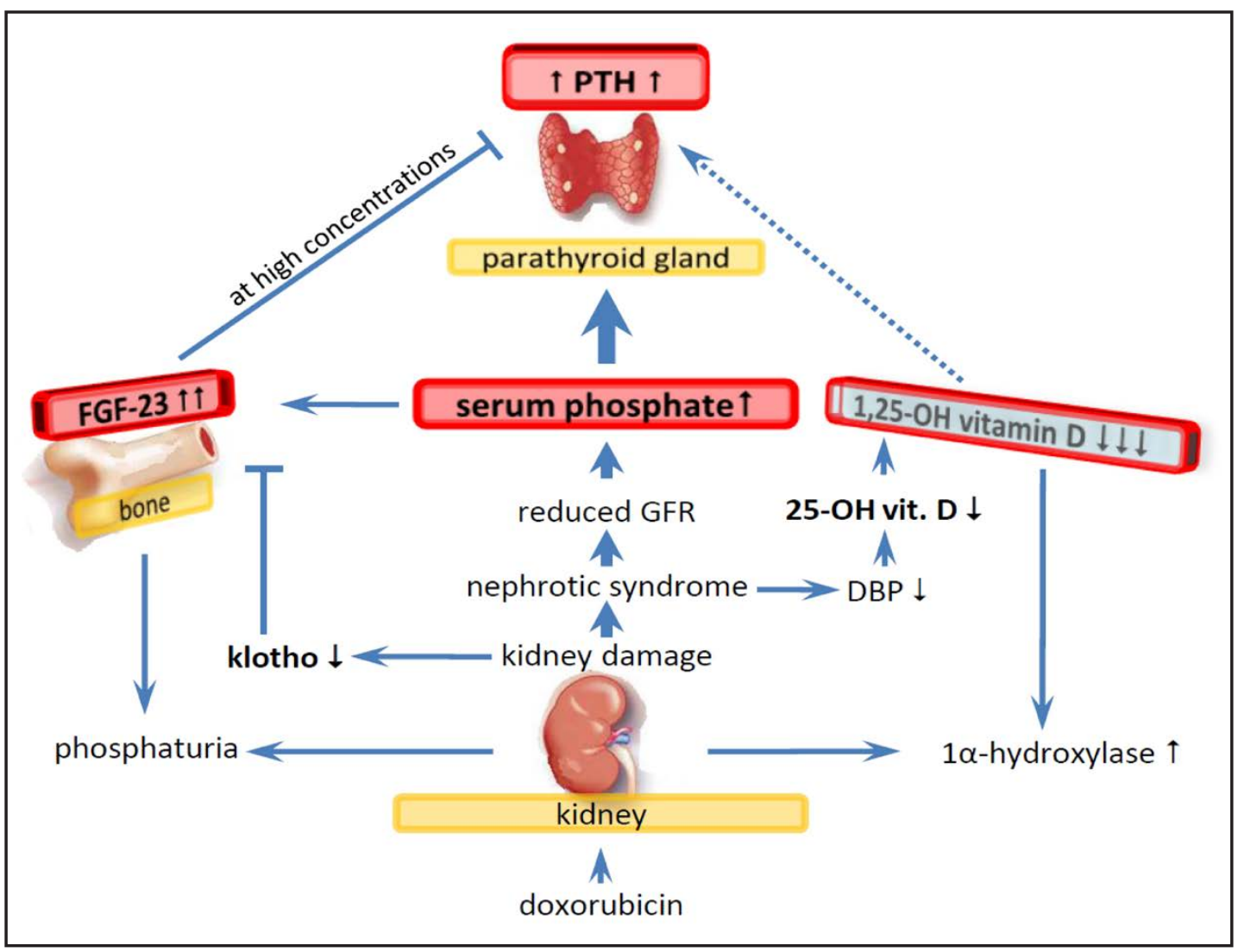

Fig. 8. Pathophysiologic events leading to SHPT in doxorubicin-induced nephropathy. According to our findings, persistent hyperphosphatemia is the key inductor of SHPT in this model which can completely be prevented by a low-phosphorus diet. Vitamin D deficiency does not seem to play a major role. Also see reference 32 .

whereas treatment with $25-\mathrm{OH}$ vitamin $\mathrm{D}$ or $1,25-\mathrm{OH}$ vitamin $\mathrm{D}$ was not able to prevent SHPT. The results of this study are clearly in favor of a phosphocentric view of the development of SHPT (Fig. 8) and reveal a close relationship between phosphate retention and FGF23 secretion throughout all groups (AKI mice, CKD 1-3 and CKD 4-5 mice). Our findings are in close agreement with a study in rats with adenine-induced CKD that were treated with the phosphate binder sevelamer showing a decrease in phosphate and FGF23 concentration and amelioration of SHPT [21]. Surprisingly, vitamin D deficiency and its correction appeared to be less relevant in this model which might be explained by constant concentrations of ionized calcium.

Interestingly, SHPT was less pronounced in AKI mice at day 10 and day 30 compared to CKD mice despite highest phosphate concentrations in the former group. This result might be explained by a direct inhibitory effect of excessively high FGF23 levels on PTH secretion [22]. Our data show that the increase in FGF23 precedes SHPT and that both hormones function to prevent hyperphosphatemia in CKD 4-5 mice at day 30. Treating mice with a low-phosphorus diet after day 10, when only FGF23 was elevated, prevented subsequent SHPT, while FGF23 concentrations were maintained. This finding suggests that factors other than hyperphosphatemia drive FGF23 secretion in this context, e.g. renal damage. According to a recent study, FGF23 increased rapidly within 24 hours after onset of AKI in both mice and patients that was not attributable to reduced clearance [23].

In this model, despite the long half-time of $25-\mathrm{OH}$ vitamin $\mathrm{D}$, we observed severe vitamin $\mathrm{D}$ deficiency that occurred within a remarkably short time of 10 days after induction 


\section{Kidney Blood Pressure Research}

Kidney Blood Press Res 2015;40:153-165

\begin{tabular}{l|l}
\hline DOI: 10.1159/000368491 & (C) 2015 S. Karger AG, Basel
\end{tabular}

Published online: March 29, 2015

www.karger.com/kbr

Bohnert/Daniel/Amann/Voelkl/Alesutan/Lang/Heyne/Häring/Artunc: Secondary Hyperparathyroidism And Proteinuric Mouse Model

of proteinuria. This finding is best explained by the rapid onset of urinary losses of both $25-0 H$ vitamin D and 1,25-OH vitamin D. Indeed, we detected both vitamin D metabolites in the urine. Due to the ongoing proteinuric loss, we were unable to correct the 1,25-vitamin D deficiency in severely proteinuric CKD 4-5 mice despite the application of very high doses of 1,25-vitamin D that otherwise would lead to massive hypercalcemia and aortic calcification [24]. None of these features were observed in our mice. Interestingly, vitamin $\mathrm{D}$ deficiency was accompanied by an increased expression of renal $1 \alpha$-hydroxylase despite elevated FGF23 concentrations that would normally decrease expression of this enzyme. This result might be explained by the interruption of the negative feedback of 1,25-vitamin $\mathrm{D}$ on renal $1 \alpha$-hydroxylase in the presence of massive 1,25-vitamin D deficiency [25]. However, other animal studies with 1,25-vitamin D-deficient CKD models have also reported increased renal $1 \alpha$-hydroxylase expression [26,27]. These results seem to contradict findings in an earlier study with CKD patients, in whom $1 \alpha$-hydroxylase activity analyzed in kidney biopsies was found to be reduced [28]. It must be mentioned that both synthesis and degradation by 24-hydroxylase govern vitamin D metabolism and that differences in 24-hydroxylase expression could also contribute to vitamin D deficiency [26]. Our data show that 24-hydroxylase expression was massively induced by vitamin D treatment, possibly preventing normalization of vitamin D status in CKD mice.

Klotho expression was reduced from day 10 forward in all mice, and this effect was inversely related to the severity of the model and kidney damage expressed as GSI and TSI ( $\mathrm{r}=-0.82$ and -0.56 , respectively). These data suggest that klotho expression might be reduced early in kidney disease, resulting in FGF23 resistance and a high inverse correlation of FGF23 and klotho expression across all groups ( $\mathrm{r}=-0.66)$. In hemodialysis patients, the plasma concentration of soluble $\alpha$-klotho, which is thought to represent renal klotho expression, was reduced, while FGF23 levels were increased [29].

The strength of this study lies in the use of a mouse model of SHPT that can be exploited for further studies using genetically modified mice. So far, almost all studies investigating SHPT have used rats. The reason for this might be the lack of a CKD model in mice, whereas many models have been described in rats (e.g. Anti-GBM [6], 5/6 nephrectomy [24] or adenine-feeding [21]). Our model is an adaptation of the adriamycin model of nephrosis in rats, which was first described by Bertani in 1982 [30]. This model, however, is limited to certain mouse strains [31], and the widely utilized C57Bl/6 mouse strain is resistant. The model differs from clinical practice with CKD patients in that vitamin D deficiency in patients is commonly not caused by proteinuria and 1,25-vitamin D deficiency can usually be overcome by oral substitution. However, vitamin D deficiency in CKD patients can be induced by urinary losses when there is a massive nephrotic syndrome $[13,14]$. Our data show that in this situation, the most effective treatment of vitamin D deficiency would be the application of native $25-\mathrm{OH}$ vitamin D instead of $1,25-\mathrm{OH}$ vitamin D as $1 \alpha$-hydroxylase activity was increased and administered $1,25-\mathrm{OH}$ vitamin $\mathrm{D}$ would not stay in circulation.

\section{Conclusion}

This study provides further evidence for a crucial role of phosphate retention in the development of SHPT that could be completely prevented by restricting phosphorus once FGF23 plasma concentrations become elevated.

\section{Disclosure Statement}

The results presented in this paper have not been published previously in whole or part. All authors declared that they have no conflict of interest related to this study. 


\section{Kidney \\ Blood Pressure Research}

\section{Acknowledgement}

We thank Andrea Janessa for her valuable support during qRT-PCR measurements. We acknowledge the support by the Deutsche Forschungsgemeinschaft and the Open Access Publishing Fund of Tübingen University.

\section{References}

1 Yamashita T, Yoshioka M, Itoh N: Identification of a novel fibroblast growth factor, FGF-23, preferentially expressed in the ventrolateral thalamic nucleus of the brain. Biochem Biophys Res Commun 2000;277:494498.

2 Shimada T, Kakitani M, Yamazaki Y, Hasegawa H, Takeuchi Y, Fujita T, Fukumoto S, Tomizuka K, Yamashita T: Targeted ablation of Fgf23 demonstrates an essential physiological role of FGF23 in phosphate and vitamin D metabolism. J Clin Invest 2004;113:561-568.

3 Larsson T, Nisbeth U, Ljunggren O, Jüppner H, Jonsson KB: Circulating concentration of FGF-23 increases as renal function declines in patients with chronic kidney disease, but does not change in response to variation in phosphate intake in healthy volunteers. Kidney Int 2003;64:2272-2279.

4 Evenepoel P, Meijers B, Viaene L, Bammens B, Claes K, Kuypers D, Vanderschueren D, Vanrenterghem Y: Fibroblast growth factor-23 in early chronic kidney disease: additional support in favor of a phosphatecentric paradigm for the pathogenesis of secondary hyperparathyroidism. Clin J Am Soc Nephrol 2010;5:1268-1276.

5 Goodman WG, Quarles LD. Development and progression of secondary hyperparathyroidism in chronic kidney disease: Lessons from molecular genetics. Kidney Int 2008;74:276- 288.

6 Hasegawa H, Nagano N, Urakawa I, Yamazaki Y, Iijima K, Fujita T, Yamashita T, Fukumoto S, Shimada T: Direct evidence for a causative role of FGF23 in the abnormal renal phosphate handling and vitamin D metabolism in rats with early-stage chronic kidney disease. Kidney Int 2010;78:975-980.

7 Isakova T, Wolf MS: FGF23 or PTH: which comes first in CKD ? Kidney Int 2010;78:947-949.

8 Urakawa I, Yamazaki Y, Shimada T, Ijima K, Hasegawa H, Okawa K, Fujita T, Fukumoto S, Yamashita T:Klotho converts canonical FGF receptor into a specific receptor for FGF23. Nature 2006;444:770-774.

9 KDIGO CKD Work Group: Kdigo clinical practice guideline for the diagnosis, evaluation, prevention, and treatment of chronic kidney disease-mineral and bone disorder (ckd-mbd). Kidney Int 2009;76:S1-S130.

10 Okša A, Spustová V, Krivošíková Z, Gazdíková K, Fedelešová V, Lajdová I, Štefíková K, Bernasovská G, Žilinská Z, Dzúrik R: Effects of long-term cholecalciferol supplementation on mineral metabolism and calciotropic hormones in chronic kidney disease. Kidney Blood Press Res 2008;31:322-329.

11 Silver J, Yalcindag C, Sela-Brown A, Kilav R, Naveh-Many T: Regulation of the parathyroid hormone gene by vitamin D, calcium and phosphate. Kidney Int Suppl 1999;73:S2-7.

12 Thrailkill KM, Jo CH, Cockrell GE, Moreau CS, Fowlkes JL: Enhanced excretion of vitamin D binding protein in type 1 diabetes: a role in vitamin D deficiency? J Clin Endocrinol Metab 2011;96:142-149.

13 Doorenbos CR, de Cuba MM, Vogt L, Kema IP, van den Born J, Gans RO, Navis G, de Borst MH: Antiproteinuric treatment reduces urinary loss of vitamin D-binding protein but does not affect vitamin D status in patients with chronic kidney disease. J Steroid Biochem Mol Biol 2012;128:56-61.

14 Mittal SK, Dash SC, Tiwari SC, Agarwal SK, Saxena S, Fishbane S: Bone histology in patients with nephrotic syndrome and normal renal function. Kidney Int 1999;55:1912-1919.

15 Artunc F, Nasir O, Amann K, Boini KM, Haring HU, Risler T, Lang F: Serum- and glucocorticoid-inducible kinase 1 in doxorubicin-induced nephrotic syndrome. Am J Physiol Renal Physiol 2008;295:F1624-F1634.

16 Matsui I, Hamano T, Tomida K, Inoue K, Takabatake Y, Nagasawa Y, Kawada N, Ito T, Kawachi H, Rakugi H, Imai E, Isaka Y: Active vitamin D and its analogue, 22-oxacalcitriol, ameliorate puromycin aminonucleosideinduced nephrosis in rats. Nephrol Dial Transplant 2009;24:2354-2361.

17 Artunc F, Ebrahim A, Siraskar B, Nasir O, Rexhepaj R, Amann K, Friedrich B, Risler T, Lang F. Responses to diuretic treatment in gene-targeted mice lacking serum- and glucocorticoid-inducible kinase 1. Kidney Blood Press Res. 2009; 32:119-27 


\section{Kidney \\ Blood Pressure Research}

\section{Kidney Blood Press Res 2015;40:153-165}

\begin{tabular}{l|l}
\hline DOI: $10.1159 / 000368491$ & (C) 2015 S. Karger AG, Basel
\end{tabular}

Published online: March 29, 2015

www.karger.com/kbr

18 El Nahas AM, Bassett AH, Cope GH, Le Carpentier JE: Role of growth hormone in the development of experimental renal scarring. Kidney Int 1991;40:29-34.

19 Veniant M, Heudes D, Clozel JP, Bruneval P, Menard J: Calcium blockade versus ACE inhibition in clipped and unclipped kidneys of 2K-1C rats. Kidney Int 1994;46:421-429.

20 Kuro-o M: Klotho, phosphate and FGF-23 in ageing and disturbed mineral metabolism. Nat Rev Nephrol 2013;9:650-660.

21 Nagano N, Miyata S, Abe M, Kobayashi N, Wakita S, Yamashita T, Wada M: Effect of manipulating serum phosphorus with phosphate binder on circulating PTH and FGF23 in renal failure rats. Kidney Int 2006;69:531-537.

22 Ben-Dov IZ, Galitzer H, Lavi-Moshayoff V, Goetz R, Kuro-o M, Mohammadi M, Sirkis R, Naveh-Many T, Silver J: The parathyroid is a target organ for FGF23 in rats. J Clin Invest 2007;117:4003-4008.

23 Christov M, Waikar SS, Pereira RC, Havasi A, Leaf DE, Goltzman D, Pajevic PD, Wolf M, Juppner H: Plasma FGF23 levels increase rapidly after acute kidney injury. Kidney Int 2013;84:776-785.

24 Noonan W, Koch K, Nakane M, Ma J, Dixon D, Bolin A, Reinhart G: Differential effects of vitamin D receptor activators on aortic calcification and pulse wave velocity in uraemic rats. Nephrol Dial Transplant 2008;23:3824-3830.

25 Takeyama K, Kitanaka S, Sato T, Kobori M, Yanagisawa J, Kato S: Hydroxyvitamin D3 1a-hydroxylase and vitamin D synthesis. Science 1997;277:1827-1830.

26 Helvig CF, Cuerrier D, Hosfield CM, Ireland B, Kharebov AZ, Kim JW, Ramjit NJ, Ryder K, Tabash SP, Herzenberg AM, Epps TM, Petkovich M: Dysregulation of renal vitamin D metabolism in the uremic rat. Kidney Int 2010;78:463-472.

27 Takemoto F, Shinki T, Yokoyama K, Inokami T, Hara S, Yamada A, Kurokawa K, Uchida S: Gene expression of vitamin D hydroxylase and megalin in the remnant kidney of nephrectomized rats. Kidney Int 2003;64:414-420.

28 Satomura K, Seino Y, Yamaoka K, Tanaka Y, Ishida M, Yabuuchi H, Tanaka Y, DeLuca HF: Renal 25-hydroxyvitamin D3-1-hydroxylase in patients with renal disease. Kidney Int 1988;34:712-716.

29 Nowak A, Friedrich B, Artunc F, Serra AL, Breidthardt T, Twerenbold R, Peter M, Mueller C: Prognostic value and link to atrial fibrillation of soluble Klotho and FGF23 in hemodialysis patients. PLoS One 2014;9:e100688.

30 Bertani T, Poggi A, Pozzoni R, Delaini F, Sacchi G, Thoua Y, Mecca G, Remuzzi G, Donati MB: Adriamycininduced nephrotic syndrome in rats: sequence of pathologic events. Lab Invest 1982;46:16-23.

31 Zheng Z, Schmidt-Ott KM, Chua S, Foster KA, Frankel RZ, Pavlidis P, Barasch J, D'Agati VD, Gharavi AG: A Mendelian locus on chromosome 16 determines susceptibility to doxorubicin nephropathy in the mouse. Proc Natl Acad Sci USA 2005;102:2502-2507.

32 Torres PA, De Brauwere DP: Three feedback loops precisely regulating serum phosphate concentration. Kidney Int 2011;80:443-445. 